\title{
CD8 Expressing Cell Count
}

National Cancer Institute

\section{Source}

National Cancer Institute. CD8 Expressing Cell Count. NCI Thesaurus. Code C103811.

The determination of the amount of the CD8 expressing cells in a sample. 